\title{
Proteus sp. - an opportunistic bacterial pathogen - classification, swarming growth, clinical significance and virulence factors
}

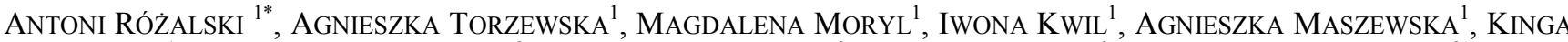

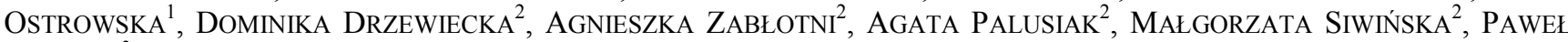 \\ STĄCZEK $^{3}$ \\ ${ }^{1}$ Department of Immunobiology of Bacteria \\ ${ }^{2}$ Department of General Microbiology \\ ${ }^{3}$ Department of Genetics of Microorganisms \\ Institute of Microbiology, Biotechnology and Immunology, University of Łódź, Banacha 12/16, 90-237 Łódź, Poland \\ *E-mail: rozala@biol.uni.lodz.pl
}

\section{Abstract}

The genus Proteus belongs to the Enterobacteriaceae family, where it is placed in the tribe Proteeae, together with the genera Morganella and Providencia. Currently, the genus Proteus consists of five species: P. mirabilis, $P$. vulgaris, $P$. penneri, $P$. hauseri and $P$. myxofaciens, as well as three unnamed Proteus genomospecies. The most defining characteristic of Proteus bacteria is a swarming phenomenon, a multicellular differentiation process of short rods to elongated swarmer cells. It allows population of bacteria to migrate on solid surface. Proteus bacteria inhabit the environment and are also present in the intestines of humans and animals. These microorganisms under favorable conditions cause a number of infections including urinary tract infections (UTIs), wound infections, meningitis in neonates or infants and rheumatoid arthritis. Therefore, Proteus is known as a bacterial opportunistic pathogen. It causes complicated UTIs with a higher frequency, compared to other uropathogens. Proteus infections are accompanied by a formation of urinary stones, containing struvite and carbonate apatite. The virulence of Proteus rods has been related to several factors including fimbriae, flagella, enzymes (urease - hydrolyzing urea to $\mathrm{CO}_{2}$ and $\mathrm{NH}_{3}$, proteases degrading antibodies, tissue matrix proteins and proteins of the complement system), iron acqusition systems and toxins: hemolysins, Proteus toxin agglutinin (Pta), as well as an endotoxin - lipopolysaccharide (LPS). Proteus rods form biofilm, particularly on the surface of urinary catheters, which can lead to serious consequences for patients. In this review we present factors involved in the regulation of swarming phenomenon, discuss the role of particular pathogenic features of Proteus spp., and characterize biofilm formation by these bacteria.

KEY WORDS: Proteus, pathogenicity, mechanisms of virulence

\section{Classification and environmental distribution of Proteus rods}

The genus Proteus, which was described for the first time by Hauser in 1885, belongs to the Enterobacteriaceae family. In this family it is placed in the tribe Proteeae, together with the genera Morganella and
Providencia. Proteus rods are distinguishable from most other genera by their ability to swarm across agar surfaces of solid media. The differentiation of Proteus rods according to the results of biochemical tests is shown in 
the table 1. The genus Proteus currently consists of five species: $P$. mirabilis, $P$. vulgaris, $P$. penneri, $P$. hauseri and $P$. myxofaciens, as well as three unnamed Proteus genomospecies. Proteus myxofaciens is the only Proteus species without any significance in the pathogenicity of humans, it has been isolated from living and dead larvae of the gypsy moth Porteria dispar (O'HARA et al. 2000, JANDA \& ABBOT 2006). Recently described results of the analysis of partial sequences of the rpoB gene encoding the $\beta$-subunit of RNA polymerase, led to the conclusion that a genus-level genetic distance exists between $P$. myxofaciens and the species of the Proteus-Providencia group. Classification of $P$. myxofaciens in a new genus Cosenzaea gen. nov. has therefore been proposed (GIAMMANCO et al. 2011).

TABLE 1. Biochemical tests used in differentiation within the genus Proteus (RÓżALSKI \& STĄCZEK 2010, 2011). + 90-100\% positive, - $0-9.9 \%$ positive; $\mathrm{S}$ - susceptible, $\mathrm{R}$ - resistant, $\mathrm{V}$ - variable.

\begin{tabular}{lccccc}
\hline Test & P. mirabilis & P. vulgaris & P. penneri & P. hauseri & P. myxofaciens \\
\hline Salicin fermentation & - & + & - & - & - \\
Maltose fermentation & - & + & + & + & + \\
$\begin{array}{l}\text { D-Xylose fermentation } \\
\text { Esculin hydrolysis }\end{array}$ & + & + & + & + & - \\
$\begin{array}{l}\text { Ornithine } \\
\text { decarboxylase }\end{array}$ & + & - & - & - & - \\
$\begin{array}{l}\text { Indole production } \\
\begin{array}{l}\text { Chloramphenicol } \\
\text { susceptibility }\end{array}\end{array}$ & - & + & - & + & - \\
\end{tabular}

Proteus microorganisms are widely distributed in the natural environment, including polluted water, soil, and manure. Due to their proteolytic activity, the ability to hydrolyze urea to ammonia and carbon dioxide, as well as the oxidative deamination of amino acids, these bacteria are involved in

\section{Swarming phenomenon}

Swarming is a multicellular differentiation phenomenon that allows a population of bacteria to migrate on a solid surface in a coordinate manner. It is important in movement of Proteus rods to new locations and most probably helps them in the colonization macroorganisms. It involves cellto-cell signaling and multicellular interactions and is connected with the possibility of morphological differentiation of bacteria depending on growth media. Proteus are the decomposing of the organic matter of the animal origin. They are also present in the intestines of humans and animals. P. mirabilis was most frequently isolated from dogs, cows and birds, whereas $P$. vulgaris was most frequently isolated from pigs and coldblooded vertebrates (JANDA \& ABBOT 2006).

dimorphic bacteria, which in liquid media are motile, peritrichously flagellated short rods (1.0 to $2.0 \mu \mathrm{m}$ in length with $6-10$ flagella). These bacteria are called swimmer cells. However, when transferred onto solid media these short rods change into elongated (20-80 $\mu \mathrm{m}$ in length), hyperflagellated, multinucleated, nonseptated swarmer cells. The latter migrate out from the inoculation site as long as the population of swarmer cells is reduced on solid surfaces. Then, the 
consolidation process takes place. In this period of swarming growth, the long rods disintegrate to short bacteria. The processes of differentiation and dedifferentiation of Proteus bacteria are cyclic. It results in the formation of characteristic rings of bacterial growth on the agar plate (fig. 1) (Verstraeten et al. 2008, MorgensteIn et al. 2010, RÓŻALSKI \& STĄCZEK 2010).

Differentiation of swimmer cells into swarmer cells is induced by the contact of bacteria with a solid surface and the inhibition of flagellar rotation. It was found that the addition of thickening agents to liquid media resulted in differentiation of short rods to swarmer cells. A similar effect was obtained when antiflagellar antibodies were added to liquid medium (BELAS \& SUVANASUTHI 2005). Mutations in gene flaA encoding flagellin, as well in genes involved in flagellum assembly led to the inhibition of Proteus short rods differentiation (BELAS 1994). Lipopolysaccharide (LPS), a surface component of these bacteria, seems to be important in the swarming phenomenon, however, its exact role has not been

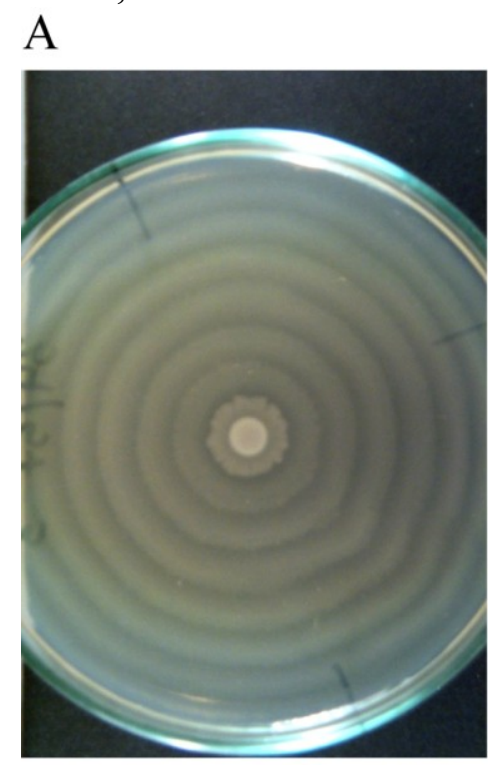

B

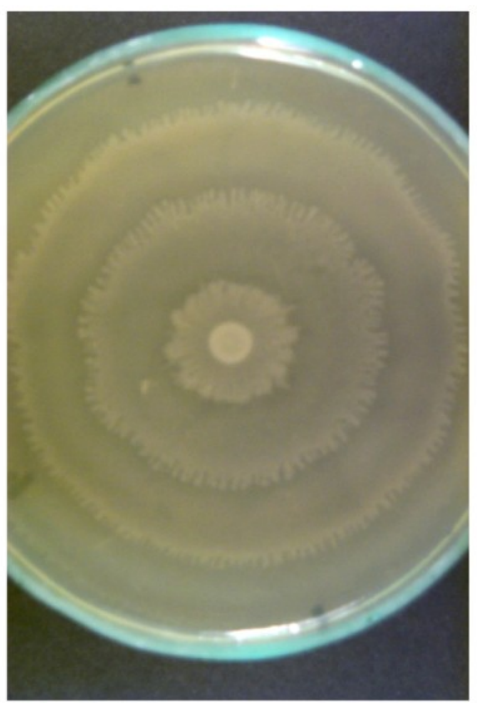

described. Mutation in the $w z z$ region encoding $\mathrm{O}$-antigen chain, as well as in genes $w a a D$ and waaC required for the core region of LPS are impaired in swarming growth (MORGENSTEIN et al. 2010). Swarmer cells translocation is facilitated by an extracellular acidic polysaccharide designated as $\mathrm{Cmf}$ (colony migration factor), which acts as a lubricant, reducing surface friction (GYGI et al. 1995). This capsular polysaccharide is structurally identical with the O-specific part of Proteus LPS serogroup O6 (KNIREL et al. 2011). Most likely, Proteus O-specific polysaccharides are important for the swarming. It was found that the Re mutant of P. mirabilis $\mathrm{R} 45$ producing LPS having only the lipid $\mathrm{A}$ and Kdo region was unable to swarm. The Ra mutant of $P$. mirabilis R110 containing lipid $\mathrm{A}$ and a complete core region expressed only a limited ability for migration on the solid medium, whereas most of S-forms of $P$. mirabilis, $P$. vulgaris and $P$. penneri could swarm vigorously (BABICKA 2001, KWIL 2003).

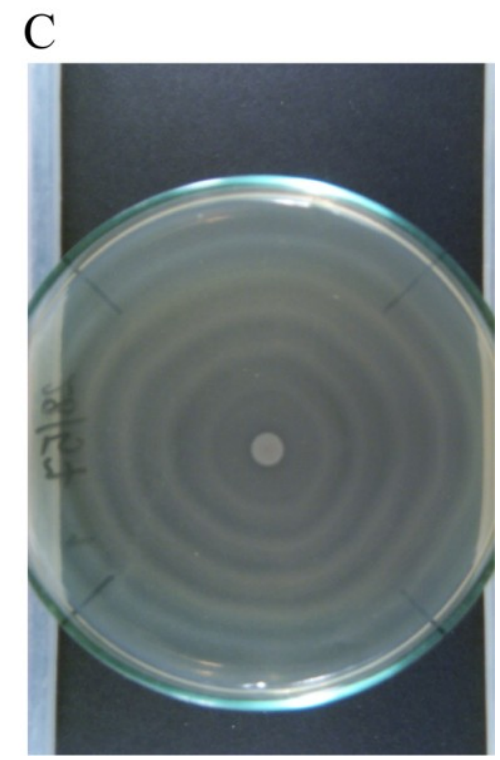

Figure 1. Swarming growth of three strains P. mirabilis strains 34/57 (A), 14/57 (B) and 26/57 (C) on a agar plate (KWIL data not published).

Swarming growth is characteristic for population of bacteria, thus it is dependent on multicellular interactions and cell to cell signaling in the phenomenon described as quorum sensing. It was found that extracellular signal AI-2 (autoinducer-2) does not play a role in swarming. Cyclic dipeptides were also shown as $P$. mirabilis signaling molecules out of importance in swarming (RATHER 2005). Other signal molecules 
$\mathrm{N}$-acyl homoserine lactones crucial in quorum sensing are not produced by $P$. mirabilis (MorgensteIn et al. 2010). Nevertheless, it was shown that $N$-acyl homoserine lactones added to the media are able to accelerate migration of some $P$. mirabilis strains (STAŃKOWSKA et al. 2008). In earlier studies, glutamine was found to be able to initiate swarming on minimal media (ALLISON et al. 1993). Swarming growth is also influenced by fatty acids. Oleic acid stimulates, whereas lauric and myristic acids inhibit this phenomenon, respectively (LIAW et al. 2004). The mechanism by which glutamine and fatty acids play a role in the swarming process as signals for cell to cell communication is currently unknown. In swarmer cell differentiation putrescine was described as a biochemical signal, however, the mechanism by which this amine regulates swarming is not clear. Most probably putrescine can form a complex with galacturonic acid which is component of CPS. This suggests a possibility that putrescine complexed with cell surface polysaccharide acts as a signal factor or putrescine regulates expression of CPS (RATHER 2005, MORGENSTEIN et al. 2010).

A number of factors playing a role in swarming regulations have been recognized (DANIELS et al. 2004, RATHER 2005, VERSTRAETEN et al. 2008, MORGENSTEIN et al. 2010). The most important gene involved in upregulation of flagellin production is flhDC, class 1 gene of flagellar regulon. This gene encodes FlhD2C2 complex, a heterotetrameric transcriptional regulator, which also regulates the expression of additional genes required for swarmer cells differentiation. The expression of $f l h D C$ increases 10-fold during initiation of swarmer cells differentiation and it is influenced by a variety of environmental factors and regulating genes. FlhD2C 2 activates class 2 genes coding basal body and hook proteins of flagella, as well as $\sigma 28$ factor, which activates class 3 genes required for synthesis of flagellin and flagellum assembly. FlhD2C2 activity is regulated by two identified factors DisA (decarboxylase inhibitor of swarming) and Lon protease (ATP-dependent protease).
DisA most probably inhibits the assembly of heterotetramer or its binding to DNA (MORGENSTEIN et al. 2010).

Proteus has 16 predicted two-component systems - TCS (PEARSON et al. 2008). TCS consists of sensor kinase, which activates response regulator DNA - a binding protein controlling gene expression. Two of TCS Rcs and Rpp are involved in swarming regulation (MORGENSTEIN et al. 2010). Rcs system contains RcsC sensor kinase, RcsB response regulator, $\mathrm{RcsD}$ intermediate transferring phosphate to the RcsB and RcsF which is an outer membrane lipoprotein. Mutation in the genes coding Rcs system in $P$. mirabilis lead to the hyperswarming phenotype, most probably due to an increased expression of the flhDC. P. mirabilis Rcs mutant grows in liquid media as elongated cells. The Rpp system consists of RppA response regulator and $\mathrm{RppB}$ histidine sensor kinase like protein. Mutation in the Rpp system in $P$. mirabilis also results in a hyperswarming phenotype.

flhDC expression is also regulated by several proteins including Umo, MrpJ, WosA, Lrp and RsmA. Umo A-D proteins (umo upregulated expression of the $f l h D C$ master operon) are located in the cell membrane and periplasm. Mutant defective in production of UmoD protein is not able to swarm, however, such effect was not noticed in the case of UmoA and UmoC (DUFOUR et al. 1998).

mrpJ gene is located in the mrp operon encoding MR/P fimbriae, which are required for sessile lifestyle of bacteria (NIELUBOWICZ \& Mobley 2010). It is opposite to the swimming or swarming phenotype of bacteria. The existence of bacteria in one of two forms is regulated by mrpJ gene product - MrpJ protein, a transcriptional regulator. It binds the $f l h D C$ promoter, which causes its repression and results in loss of motility of bacteria (PEARSON \& MOBLEY 2008).

wosA gene coding WosA protein, is overexpressed in strains exhibiting hyperswarming phenotype (wos - wild type onset superswarming). WosA overexpression increases the expression of $f h l D C$ and leads to a differentiation of swarmer cells in liquid 
media. The hyperswarming wos $A$ bacteria move quickly and spend less time in the consolidation phase. wosA expression is growth phase dependent, as well as it is partially dependent upon the expression of flaA gene encoding the flagellar filament (HATT \& RATHER 2008).

Leucine responsive protein (Lrp) is a transcriptional global regulator involved in regulating different processes including amino acids synthesis, peptide transport, and pilin biogenesis (RATHER 2005, MORGENSTEIN et al. 2010). In P. mirabilis strains Lrp plays a role in the regulation of the swarming phenomenon, most probably its action leads to the inhibition of hyperflagellation. Mutation in $\operatorname{lrp}$ results in a decrease in the flhDC, flaA and hpm (hemolysin) expression and, in consequence, a nonswarming phenotype (HAY et al. 1997). Lrp is well known to respond to leucine and to a lesser extent to alanine. Recently, it was found that it also responds to methionine and is sensitive to isoleucine, histidine and thyrosine (HART \& BLUMENTHAL 2010). In additional studies HART et al. (2011) showed that recognition of DNA by the helix-turn-helix motif of Lrp is modulated by the N-terminal tail.

RsmA - repressor of secondary metabolites is a member of regulatory systems involved in the expression control of genes which code factors commited to stationary growth processes. This protein stabilizes mRNA. In $P$. mirabilis RsmA is $6.8 \mathrm{kDa}$ protein containing 62 amino acids. Increasing its expression results in the inhibition of swarmer cells differentiation and production

\section{Pathogenicity}

Proteus rods are opportunistic bacterial pathogens which under favorable conditions cause urinary tract infections (UTIs), wound infections, meningitis in neonates or infants and rheumatoid arthritis (O'HARA et al. 2000, JANDA \& ABBOT 2006). KALRA et al. (2011) reviewed endocarditis due to Proteus species and Окімото et al. (2010) reported P. mirabilis pneumonia. Brain abscesses during $P$. vulgaris bacteremia were described of hemolysin, protease, urease and flagellin (LIAW et al. 2003). Overexpressing of $r s m A$ led to repression of $f l h D C$ (MORGENSTEIN et al. 2010).

The role of the swarming phenomenon in the pathogenicity of Proteus bacteria (see below) is till now unclear. It was shown that swarmer cells demonstrate higher production of urease, HpmA hemolysin and $\operatorname{IgA}$ metaloprotease ZapA, as well as flagellin synthesis, as compared to swimmer cells (RATHER 2005, JACOBSEN et al. 2008). There is some controversy concerning invasiveness of swarmer cells. ALLISON et al. 1992 showed in vitro that this morphotype could invade uroepithelial cells, whereas nonflagellated and nonswarming forms were noninvasive. Other authors (RÓŻALSKI et al. 1986, CHIPPENDALE et al. 1994) showed the short rods as invasive forms, rather than swarmer cells. These results were confirmed by JANSEN et al. (2003) in a mouse model of ascending UTI. These authors have found that the predominant cell type in the urinary tract are short swimmer cells but not elongated swarmer cells. Recently, FUJIHARA et al. (2011) suggested that $P$. mirabilis cells differentiate into hyperflagellated and multinucleated swarmer cells in acidic $\mathrm{pH}$ of the host's urine and differentiate back into swimmer forms, when the urinary $\mathrm{pH}$ is increased and it is alkaline after urease action (see below). In acidic condition swarmer cells exhibit higher cytotoxicity against T24 line. In alkaline condition $P$. mirabilis showed few elongated cells with high number of flagella and cytotoxic activity.

by BLOCH et al. (2010). However, it should be stressed that Proteus bacteria cause UTIs with higher frequency. This type of infections is classified as uncomplicated or complicated. Uncomplicated infections occur in patients who are otherwise considered healthy, whereas complicated infections usually take place in patients with an urinary catheter in place or with structural and/or functional abnormalities in the urinary tract, suffering 
from another illness, immunocompromised, as well as after surgical intervention in the urogenital system. It was found that Escherichia coli is a common cause of uncomplicated infections. Complicated UTIs might be polymicrobial and are usually caused by Gram-negative bacteria Proteus spp., Providencia stuartii, Morganella morganii, E. coli, Pseudomonas aeruginosa, Klebsiella pneumoniae as well as some Grampositive bacteria (NiElubOWICZ \& MOBLEY 2010). Proteus rods can cause hematogenous infections and ascending infections, however, the latter are more common for these microorganisms. The ascending infections comprise colonization subsequently urethra, bladder, ureters and kidneys. P. mirabilis causes UTIs with the highest frequency among all Proteus species. These bacteria are a common cause of complicated UTIs with the frequency of $12 \%$ and catheter associated bacteriuria (WARREN 1996, JACOBSEN et al. 2008). They also cause uncomplicated lower urinary tract infections, however less frequently. CHLABICZ et al. (2011) have found in Poland uncomplicated $P$. mirabilis infections with the frequency of $3.4 \%$.

The virulence of Proteus rods has been related to several factors including fimbriae; flagella; enzymes: urease, hydrolyzing urea to $\mathrm{CO}_{2}$ and $\mathrm{NH}_{3}$; proteases degrading antibodies, tissue matrix proteins and proteins of complement system; iron acqusition systems and toxins: hemolysins, Proteus toxin agglutinin (Pta), as well as endotoxin lipopolysaccharide (LPS) (table 2) (COKER et al. 2000, MOBLEY 1996, RÓŻALSKI et al. 1997, RóŻALSKI 2002, NIELUBOWICZ \& MoBley 2010). BEVERIDGE (1999) postulated the possible role of outer membrane vesicles (OMVs) released from the $P$. mirabilis surface, as an alternative route of delivery of some enzymes, as well as some virulence factors.

PEARSON et al. (2011) using microarrays analyzed $P$. mirabilis gene expression in vivo from experimentally infected mice and showed 471 gene upregulated and 82 downregulated in comparison to the in vitro broth culture. Upregulated genes encoded among others mannose-resistant Proteus-like fimbriae, urease, and iron uptake systems. Genes encoding flagella were downregulated. Earlier studies (FLANNERY et al. 200) showed the identification of 94-kb PAI (pathogenicity island) designated ICEPml (integrative and conjugative elements $P$. mirabilis 1). This PAI is common to $P$. mirabilis, $P$. stuartii and $M$. morganii and carries virulence factors including Proteus toxic agglutinin (see below) and the high pathogenicity island of Yersinia spp.

The P. mirabilis genome predicts 17 distinct fimbrial operons and 13 additional orphan fimbrial genes not associated with complete operons (PEARSON et al. 2008, Nielubowicz \& Mobley 2010). The biogenesis and/or the biological role were studied for six types of fimbriae and agglutinins: MR/P (mannose resistant Proteus like fimbriae), $\mathrm{MR} / \mathrm{K}$ (mannose resistant Klebsiella hemagglutinins), PMF (Proteus mirabilis fimbriae), NAF (nonagglutinating fimbriae), ATF (ambient temperature fimbriae) and $P$. mirabilis P-like fimbriae (fimbriae, which are similar to E. coli $\mathrm{P}$ pili) (COKER et al. 2000, RochA et al. 2007b, JACOBSEN et al. 2008).

The most important $P$. mirabilis fimbriae seem to be MR/P. This type of fimbriae is encoded by mrp operon containing 10 genes located on bacterial chromosome. The main structural subunit of these fimbriae is the MrpA protein. The MrpC protein is an outer membrane platform, MrpD plays a role of a chaperon protein and $\mathrm{MrpH}$ is an adhesin located at the fimbrial tip (BAHRANI et al. 1991, Li et al. 1999, COKER et al. 2000). $\mathrm{MR} / \mathrm{P} /$ fimbriae undergo phase variation. It was found that the MrpI protein acts as P. mirabilis recombinase controlling "on/off" orientation of the $m r p$ promoter. The fimbrial genes are transcribed and $\mathrm{MR} / \mathrm{P}$ fimbriae are synthesized when the promoter is in "on" orientation (LI et al. 2002a, NIELUBOWICZ \& MOBLEY 2010). In the "off" orientation the production of fimbriae is stopped. Expression of $\mathrm{MR} / \mathrm{P}$ fimbriae is increased under oxygen limitation (LANE et al. 2009). These fimbriae contribute to biofilm formation and facilitate 
colonization of upper urinary tract and were found more often on bacterial strains which cause pyelonephritis (JANSEN et al. 2004). $\mathrm{MR} / \mathrm{P}$ fimbriae are involved in aggregative adherence to HEp-2 cells (RoCHA et al. 2007a). MR/P fimbriae elicit a strong immune response during infection. It is directed against the MrpA protein. It was found that immunization of mice with the attenuated strain of Salmonella Typhimurium expressing MrpA-TetC fusion protein led to an increase in serum level of $\operatorname{IgG}$ antibodies against MrpA and significantly reduced $P$. mirabilis colonization of bladder and kidney. TetC is a non-toxic highly immunogenic fragment of the tetanus toxin (SCAVONE et al. 2011). The presence of mrp operon was shown not only in $P$. mirabilis strains but also in other species of the Proteus genus (BABICKA 2001, KWIL, 2002, 2003, KwIL et al. data not published).

Other than $\mathrm{MR} / \mathrm{P}$ fimbriae are known to a lesser extent. $\mathrm{MR} / \mathrm{K}$ hemagglutinins were found more frequently on $P$. penneri strains than on $P$. mirabilis strains and most probably they facilitated the adherence of bacteria to the urinary catheters (JACOBSEN et al. 2008). The exact virulence role of PMF fimbriae is unclear (NiElubOwiCZ \& Mobley 2010). ZUNINO et al. (2007) by using $P$. mirabilis pmfA/mrpA-D mutant showed the specific and additive roles of $\mathrm{MR} / \mathrm{P}$ and $\mathrm{PMF}$ fimbriae in UTI caused by these bacteria. NAF fimbriae, earlier known as UCA fimbriae, allow bacteria to colonize uroepithelial cells (WRAY et al. 1986). It was found that NAF/UCA binds the following receptors: asialo- $\mathrm{GM}_{1}$, asialo- $\mathrm{GM}_{3}$, lactosyl ceramide and galectin (LEE et al. 2000, AltMAn et al. 2001). ATF fimbriae are not important in the pathogenicity of human beings (ZUNINO et al. 2000). PMP fimbriae were found on canine UTI isolates (BIJLSMA et al. 1995), however genes coding this type of fimbriae were found in human clinical isolates (PEARSON et al. 2008).

There are conflicting results concerning the importance of flagella in the infection. Since flagella mediate motility of bacteria, they seem to be required for virulence of uropathogens, particularly during ascending infection. Indeed, it was shown in vivo that flagella-negative mutant of $P$. mirabilis is less virulent, compared to the wild strain, which suggests an important role of these bacterial surface structures in the pathogenicity (MoBley et al. 1996). However, it must be stressed, that lack of flagella on $P$. mirabilis human isolate was found (ZUNINO et al. 1994). Flagella play a role of $H$ antigen and are strongly immunogenic. Bacteria can avoid immune response of human organism due to the antigenic variation process. This phenomenon is based on flagellin genes rearrangement. Flagellar antigenic variations allow bacteria to evade the action of secretory IgA antibodies directed against these organelles (BELAS 1994).

$P$. mirabilis evades the immune system response during infection thanks to the production of sIgA protease. The best characterized is $54-\mathrm{kDa}$ secreted metalloprotease ZapA, mirabilysin belonging to the serralysin family (LOOMES et al. 1990). ZapA possesses a broad spectrum of proteolytic specificity, including the activity against antibodies of $\operatorname{sg} \mathrm{A}, \operatorname{Ig} \mathrm{A} 2$ and $\operatorname{IgG}$, proteins of the complement system, cell matrix proteins, cytoskeletal proteins, as well as antimicrobial defense components of human innate system peptides hBD1 and cathelicidin LL-37 (BELAS et al. 2004, JACOBSEN et al. 2008). ZapA was found to be an important virulence factor in a rat model of $P$. mirabilis induced acute and chronic prostatitis (PHAN et al. 2008). Recently, CARSON et al. (2011) described $N$-alpha mercaptoamide dipeptides, which can be used as inhibitors of ZapA. KWIL et al. (2011) have shown the presence of the zapA operon in $P$. vulgaris and $P$. penneri strains.

It was shown that amino acid deaminase (Aad) produces $\alpha$-keto acids which serves as siderophores involved in iron acquisition (DRECHSEL et al. 1993, MASSAD et al. 1995). Recently, HIMPSI et al. (2010) described proteobactin and yersiniabactin related siderophore function in $P$. mirabilis. Zinc, another biologically important element needed for bacterial growth, is utilized by $P$. mirabilis by use of ZnuABC high affinity 
transport system (NIELUBOWICZ \& MOBLEY 2010). P. mirabilis also posses high-affinity phosphate transporter system Pst. It is postulated that this system is important in P. mirabilis virulence (JACOBSEN et al. 2008).

Urease is an urea amidohydrolase which catalyses the hydrolysis of urea to ammonia and carbamate, then digested to carbone dioxide and second molecule of ammonia (MOBLEY et al. 1995). This process results in elevation of $\mathrm{pH}$ and non-physiological alkalization of urine, which in turn induces the precipitation of magnesium and calcium ions, normally soluble in slightly acidic urine, and the formation of urinary stones, containing struvite and carbonate apatite (RÓŻALSKI et al. 1997, JACOBSEN et al. 2008, Nielubowicz \& Mobley 2010). The carbonate apatite forms an amorphous precipitate opposite to struvite, which forms crystals of defined morphology. It was found that struvite exhibits polar properties (PRYWER \& TORZEWSKA 2010, ROMANOWSKI et al. 2010).

Table 2. Virulence factors (VP), biological features (BF) and types of growth (TG) of Proteus rods in relation to the pathogenicity.

\begin{tabular}{|c|c|c|}
\hline VP/BF/TG & Specific data & Contribution to the pathogenicity \\
\hline Fimbriae & $\begin{array}{l}\text { P. mirabilis genome predicts } 17 \\
\text { distinct fimbrial operons. Six types } \\
\text { of fimbriae/agglutinins were } \\
\text { identified }\end{array}$ & $\begin{array}{l}\text { Adherence of bacteria to the epithelial tissue } \\
\text { Contribution to the biofilm formation }\end{array}$ \\
\hline Flagella & H-antigen & $\begin{array}{l}\text { Ascension of bacteria in urinary tract. Elicitation } \\
\text { of immunoresponce which can be avoid due to } \\
\text { the antigenic variation }\end{array}$ \\
\hline Invassiveness & Studied in vitro & $\begin{array}{l}\text { Penetration and internalization of bacteria into } \\
\text { host cells }\end{array}$ \\
\hline Proteases & $\begin{array}{l}\text { IgA and IgG proteases, which are } \\
\text { also able to degrade other types of } \\
\text { biologically important proteins }\end{array}$ & Diminish or elimination of phagocytosis \\
\hline $\begin{array}{l}\text { Amino acid } \\
\text { deaminase }\end{array}$ & $\begin{array}{l}\text { Production of alpha-keto acids } \\
\text { which serve as siderophores }\end{array}$ & Iron acquisition \\
\hline $\begin{array}{l}\text { Proteobactin and } \\
\text { yersiniabactin - } \\
\text { related siderophore }\end{array}$ & & \\
\hline ZnuABC & High affinity zinc transport system & Zinc utilization \\
\hline Pst & High affinity phosphate transporter & Phosphate accumulation \\
\hline Urease & $\begin{array}{l}\text { Enzyme hydrolyzing urea to } \mathrm{NH}_{3} \\
\text { and } \mathrm{CO}_{2}\end{array}$ & $\begin{array}{l}\text { Elevation of urine } \mathrm{pH} \text { level, resulting in stones } \\
\text { formation. Cytotoxicity against urinary epithelial } \\
\text { cells }\end{array}$ \\
\hline \multicolumn{3}{|l|}{ Protein toxins: } \\
\hline HmpA & Cell-bound hemolysin & Pore forming toxins mediating cytotoxicity \\
\hline HlyA & Cell free hemolysin, RTX protein & \\
\hline Pta & Cytotoxin and agglutinin & Cytotoxicity and autoagglutination of bacteria \\
\hline CPS & $\begin{array}{l}\text { Most probably structurally identical } \\
\text { with O-specific part of LPS }\end{array}$ & $\begin{array}{l}\text { Formation of biofilm. Importance in formation of } \\
\text { urinary stones. Facilitation of swarmer cells } \\
\text { translocation }\end{array}$ \\
\hline LPS & Endotoxin & $\begin{array}{l}\text { Endotoxicity. Resistance against bactericidal } \\
\text { action of the serum. Production of glycocalyx } \\
\text { important in biofilm formation }\end{array}$ \\
\hline OMVs & $\begin{array}{l}\text { Outer membrane vesicles containing } \\
\text { periplasmic constituents }\end{array}$ & Transport of virulence factors to the host tissues \\
\hline Swarming growth & $\begin{array}{l}\text { Differentiation of short rods to } \\
\text { swarmer cells }\end{array}$ & Not fully understood \\
\hline Biofilm formation & $\begin{array}{l}\text { Crystalline biofilm, particularly } \\
\text { formed on the surface of urinary } \\
\text { catheters }\end{array}$ & $\begin{array}{l}\text { Protection of bacteria against action of } \\
\text { antibiotics and immune mechanisms }\end{array}$ \\
\hline
\end{tabular}


The structural and elastic properties of struvite crystals were studied by PIECHOTA et al. (2011). Formation and morphology of struvite crystals depend on the $\mathrm{pH}$ of urine. PRYWER and TORZEWSKA (2009) have found that for $\mathrm{pH}$ in the range 7.5-9.0 struvite crystals take single and hemimorphic morphology. At higher $\mathrm{pH}$ many twin and dendritic crystals have been shown. DUMANSKI et al. (1994) has revealed that Proteus capsular polysaccharide structurally identical to O-specific polysaccharide of LPS accelerates crystallization process. TORZEWSKA et al. (2003) confirmed this observations and showed that urinary stone formation due to the urease activity, may be modified by surface $\mathrm{O}$-antigens being a part of lipopolysaccharides (LPS). The sugar composition of these polysaccharides may either enhance or inhibit the crystallization of struvite and carbone apatite depending on their chemical structure and ability to bind cations. Bacteria present within urinary stones are protected from host defense mechanisms and antibiotic treatment (LI et al. 2002b). Therefore, several phytotherapeutic compounds have been investigated to prevent urinary stone formation. For example curcumin an yellow-orange pigment non toxic to humans or animals extracted from the roots of turmeric (Curcuma longa) was shown to inhibit urease activity and consequently decrease the struvite growth. It was found in vitro experiment of struvite formation in artificial urine that the addition of curcumin increases the induction time and decreases the efficiency of formation of these crystals (TORZEWSKA et al. 2010, PRYWER \& TORZEWSKA 2010, 2012). Moreover, curcumin also inhibits biofilm formation and block swarming growth (TORZEWSKA et al. 2010). Recently, MALIC et al. (2011) reported on the development of an early warning sensor for encrustation of urinary catheters in case of Proteus infection.

It was shown that the high level of ammonia, a product of urease action also results in damage of the urinary tract epithelium. Toxic ammonia damages bladder surface glycosaminoglycans important in the prevention of bacterial adherence to the uroepithelium (JACOBSEN et al. 2008). In vitro studies performed by TORZEWSKA and RóŻALSKI (2009) showed that glycosaminoglycans have no inhibitory effect on infection-induced crystallization.

In a mouse model of ascending UTI it was found that the urease negative mutant of $P$. mirabilis was less virulent as compared to the wild strains, which suggests the important role of this enzyme in infection caused by this bacterium (JONES et al. 1990). Therefore, investigation of different substances which can be used as urease inhibitors is being performed. Recently, BERLICKI et al. (2011) described N-substituted amino-methanephosphonic and aminomethane-Pmethylphosphonic acids as effective inhibitors of $P$. mirabilis urease.

Proteus rods produce three types of cytolysins, HpmA and HlyA hemolysins and Pta cytotoxic agglutinin. HpmA is the 166 $\mathrm{kDa}$ protein, calcium-independent cell-bound hemolysin secreted by the bacteria and activated in the process mediated by $\mathrm{HpmB}$ (UPHOFF \& WELCH 1990). This hemolysin belongs to the pore forming toxins family and it is cytotoxic against a number of cells (SWIHART \& WELCH 1990). HlyA hemolysin is produced by $P$. vulgaris, $P$. penneri and P. hauseri strains (KoRONAKIS et al. 1987, RÓŻALSKI \& KOTEŁKO 1987, RÓŻALSKI \& STĄCZEK 2011). It is a strongly cytotoxic, calcium dependent $110 \mathrm{kDa}$ extracellular toxin belonging to the RTX family of proteins (RTX - repeat in toxin). Pta (Proteus toxic agglutinin), an autotransporter with subtilaselike serine protease activity exhibits bifunctional activity. It is both cytotoxin and agglutinin, which mediates autoagglutination of bacteria and cytotoxicity against human bladder and kidney cells. The vaccination of mice with Pta results in protection against P. mirabilis UTI (AlAMURI \& MOBLEY 2008).

Lipopolysaccharide is composed of three genetically and structurally distinct regions: $\mathrm{O}$-specific chain (O-antigen, O-specific polysaccharide), the core oligosaccharide and lipid A, which anchors the LPS molecule to the bacterial outer membrane (RAETZ \& 
WhITFIELD 2002). LPS containing all these three regions is produced by smooth forms of bacteria. Rough strains synthesize LPS containing lipid A and the whole core region or only its part. All three regions of Proteus LPS have been studied (RÓŻALSKI 2002, 2004, 2008, RóżALSKI et al. 2002). The differences in the structure of $\mathrm{O}$-antigens serve as a basis for the serological classification of Proteus strains. The serological classification scheme currently consists of 78 serogroups (DRZEWIECKA et al. 2004, 2008, 2010, DRZEWIECKA \& SIDORCZYK 2005, KNIREL et al. 2011). The prevalence of particular Proteus O-serogroups among clinical isolates has been changing over the time. Previously, clinical isolates were found to belong to serogroups $\mathrm{O} 3, \mathrm{O} 10$, O11, O13, O23, O27 and O30. Recently, KACA et al. (2011) studying 123 clinical isolates from Sweden and Poland showed that none of serogroups was predominant. DRZEWIECKA et al. 2010 described seven P. mirabilis strains representing serogroup O78 which can be classified in one bacterial clone widespread in hospitals, most probably due to the nosocomial infection and autoinfections. The results of detailed studies of Proteus O-specific polysaccharides are presented in the review by KNIREL et al. 2011. WANG et al. (2010) identified five putative Proteus O-antigen gene clusters and Proteus specific genes of strains classified to five serogroups.

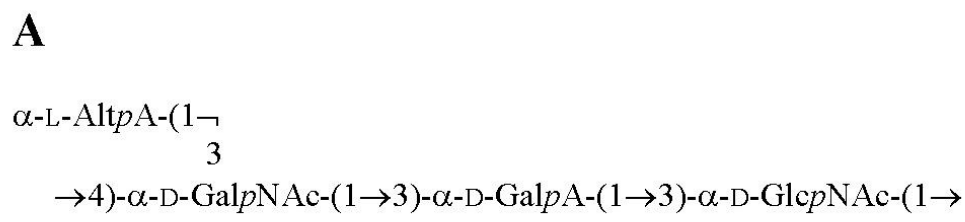

$\beta$-GalApLys-( $(1 \rightarrow 3)-\beta$-Gle $p$ NAc-( $(1 \rightarrow 6)-\alpha-G l c p N-(1 \rightarrow 4)-G a l A p-(1 \rightarrow 3)-H e p 6 P$ EtN-( $(1 \rightarrow 3)-\alpha-H e p-(1 \rightarrow 5)-\mathrm{Kdo}$

$\begin{array}{cc}2 & 4 \\ \downarrow & \uparrow \\ 7 & 1 \\ \text { DD-Hep } & \beta \text {-Glcp }\end{array}$

Figure 2. Structure of the O-specific repeating unit (A) and core oligosaccharide obtained by mild acid degradation (B) of lipopolysaccharide of Proteus mirabilis genomic strain HI 4320. Alt - altruronic acid (KNIREL et al. 2011, VINOGRADOV 2011).

The core region of Proteus lipopolysaccharides was studied by use of rough mutants or smooth forms classified into different serogroups (RADZIEJEWSKALEBRECHT et al. 1989, VINOGRADOV et al. 1994, VINOGRADOV et al. 2002). The structural diversity of the core is characteristic for Proteus spp. and makes it different from
E. coli and Salmonella (HoLst 1999, VinOgRAdOV et al. 2002). The Proteus core region is composed of two parts - an inner part, common for several number of strains and second, an outer part, which is characterized by structural variability from strain to strain. The common part is not identical in all Proteus strains and is 
subdivided into three forms known as glycoforms I-III. The outer part of the core region (outer core) contains an oligosaccharide characteristic for particular Proteus strains (VINOGRADOV et. al 2002, RÓŻALSKI 2008). The structure of the core part of $P$. mirabilis genomic strain HI4320 (formerly classified into serogroup O10) was shown by VINOGRADOV (2011) (fig. 2). The epitope specificity of the core region of $P$. penneri strains were studied by PALUSIAK and SIDORCZYK (2010). They have identified seven epitopes responsible for cross reactivity of LPS of these bacteria with appropriate antisera. The identification of genes required for the biosynthesis of the core region of P. mirabilis were described by AQUILINI et al. (2010).

LPS, released from pathogenic bacteria during infection induces a spectrum of biological activities. Therefore, LPS is also known as an endotoxin. The mechanism of biological action of the endotoxin is common to most bacteria. Its biological domain is lipid A (ŁUKASIEWICZ \& ŁUGOWSKI 2003). Proteus lipid A contains glucosamine disaccharide substituted with phosphate residues and fatty acids. It also contains 4-amino-4-deoxy-L-arabinopyranose (L-Arap4N), which quantitatively substitutes the ester-linked phosphate residue of the glucosamine backbone (SIDORCZYK et al. 1983).

Proteus LPS is associated with a broad spectrum of biological activities, and with interactions with bacterial or eukaryotic cells (RóŻALSKI 2008). LPS of S-forms of bacteria contributes to their resistance against bactericidal action of the serum (KACA \& UJAZDA 1998, MIELNIK et al. 2004, BABICKA 2001, KwIL 2003, KACA et al. 2009). The Ospecific polysaccharide chain exposed outside bacteria is involved in glycocalyx formation. Glycocalyx enables bacteria to grow in a form of biofilm on a solid surface.

Bacterial biofilm is defined as a matrixenclosed bacterial population adhering to the surfaces. Bacteria enclosed in a glycocalyx capsule are protected against the action of antibodies, as well as against other immune mechanisms (DONLAN \& COSTERTON 2002, STICKLER \& Fenley 2010). Proteus bacteria form a crystalline biofilm particularly on the surface of catheters (STICKLER 2008). It contains calcium phosphate and magnesium phosphate crystals formed due to the action of urease. JONES et al. (2007) reported that the structure of $P$. mirabilis biofilm depends on the environment (artificial urine, laboratory media) in which it occurs. Biofilms in LuriaBertani (LB) broth formed a mushroom-like architecture, while biofilms grown in urine formed a flat layer. MORYL et al. (2008) studied the effect of environmental factors such as glucose, acidic $\mathrm{pH}$, albumin and some antimicrobial agents: ciprofloxacin and methylene blue on the formation of P. mirabilis biofilm. The most inhibiting effect was observed after incubation of bacteria with albumin and in acidic growth media. KWIECINSKA-PIRÓG (2010) studied the formation of biofilm on different surfaces, and has found silicone latex surface to be better than polychloride vinyl and polypropylene surfaces for $P$. mirabilis growth in biofilm. Octenisept $\mathrm{R}$ an antiseptic products occured to be active against these bacteria growing in biofilm. Prevention and eradication of $P$. mirabilis biofilm by use of lytic bacteriophages was shown by CARSON et al. (2010). It was also found that two quorum sensing antagonists p-nitrophenyl glycerol (PNPG) and tannic acid inhibit the formation of $P$. mirabilis biofilm in artificial urine (JONES et al. 2009). P. mirabilis biofilm formation on glass and polystyrene can also be inhibited by extract of Ibucella lutea, a native plant of America (SosA \& ZUNINO 2009). MORYL (2010) observed inhibition of biofilm formation by $P$. mirabilis growing together with Escherichia coli or Providencia stuartii. STAŃKOWSKA et al. (2011) showed a significant influence of $N$-butanoyl homoserine lactone (BHL) on biofilm formation by $P$. mirabilis strain belonging to serogroup O18. Recently, SCHLAPP et al. (2011) excluded the contribution of swarmer cells in biofilm formation during the 7-day incubation of bacteria in LB broth on glass coverslips. These authors showed that 
P. mirabilis biofilm formation is a five-stage process: i) reversible adhesion to the solid surface with slow growth of bacteria, presence of elongated cells and absence of extracellular matrix, ii) irreversible bacterial adhesion, beginning of production of

\section{Summary}

Proteus bacteria inhabit the environment and they are also present in the intestines of humans and animals. These microorganisms under favorable conditions cause a number of infections including urinary tract infections (UTIs), wound infections, meningitis in neonates or infants and rheumatoid arthritis. Proteus opportunistic pathogens express virulence factors associated with adherence, motility, immunoavoidance, nutrient acquisition, host damage, biofilm formation and endotoxicity. The most defining characteristics of Proteus bacteria is the swarming phenomenon, a multicellular differentiation process of short rods to elongated swarmer cells. It allows the

\section{References}

Alamuri, P., Mobley, H.L.T. 2008. A novel autotransporter of uropathogenic Proteus mirabilis is both a cytotoxin and an agglutinin. Mol. Microbiol. 68: 997-1017.

Allison, C., Coleman, N., Jones, P.L., Huges, C. 1992. Ability of Proteus mirabilis to invade urothelial cells is coupled to motility and swarming differentiation. Infect. Immun. 60: 4740-4746.

Allison, C., LAI, H.C., Hughes, C. 1993. Cell differentiation of Proteus mirabilis is initiated by glutamine, a specific chemoattractant for swarming cells. Mol. Microbiol. 8: 53-60.

Altman, E., Harrison, B.A., LAtTA, R.K., LeE, K.K., Kelly, J.F., Timbault, P. 2001. Galectin-3mediated adherence of Proteus mirabilis to MadinDarby canine kidney cells. Biochem. Cell. Biol. 79: 783-788.

Aqulinin, E., Azevedo, J., Jimenez, N., Bouamama, L., TOMAS, J.M., REgUE, M. 2010. Functional identification of the Proteus mirabilis core lipopolysaccharide biosynthetic genes. J. Bacteriol. 192: 4413-4424.

BABICKA, D. 2001. Investigations of serological specificity of O-antigens of Proteus vulgaris O1, $\mathrm{O} 2, \mathrm{O} 4$ and $\mathrm{O} 9$ and selected biological features of extracellular materials and decreasing of elongation, iii) acceleration of bacterial growth, further decrease in elongation and halting production of extracellular material, iv) maturation of biofilm, v) detachment of bacterial cells and dispersion of biofilm.

population of bacteria to migrate in a coordinate manner on a solid surface. The role of short rods and elongated swarmer cells in the pathogenicity of Proteus bacteria is still not established. The elongated morphotype seems to be in the minority during infection. Proteus bacteria form a crystalline biofilm, particularly on the surface of catheters present in the urinary tract of patients. It contains struvite and hydroxyapatite crystals formed due to the action of urease. The results of the study on Proteus virulence and fitness factors will lead to a better understanding of infectious processes and will subsequently allow developing new methods of prevention and clinical treatment.

this species. Ph.D. thesis. University of Lodz. (In Polish).

BAHRAni, F.K., Johnson, D.E., RobBins, D. M., MoBley, H.L.T. 1991. Proteus mirabilis flagella and $\mathrm{MR} / \mathrm{P}$ fimbriae: isolation, purification, $\mathrm{N}$ terminal analysis, and serum antibody response following urinary tract infection. Infect. Immun. 59: 3574-3480.

BELAS, R. 1994. Expression of multiple flagellinencoding genes of Proteus mirabilis. J. Bacteriol., 176: 7169-7181.

Belas, R., Manos, J., Suvanasuthi, R. 2004. Proteus mirabilis ZapA metalloprotease degrades a broad spectrum of substrates, including antimicrobial peptides. Infect. Immun.72: 5159-5167.

BElas, R., SuVANASUTHI, R. 2005. The ability of Proteus mirabilis to sense surfaces and regulate virulence gene expression involves FliL, a flagellar basal body protein. J. Bacteriol. 187: 6789-6803.

BERLICKI, L., BOCHNO, M., GRABOWIECKA, A., Białas, A., KosikowsKa, P., Kafarski, P. 2011. $\mathrm{N}$-substituted aminomethanephosphonic and aminomethane- $P$-methylphosphinic acids as inhibitors of ureases. Amino Acids. DOI: 10.1007/s00726-011-0920-4. 
BEVERIDGE, T.J. 1999. Structures of Gram-negative cell walls and their derived membrane vesicles. J. Bacteriol. 181: 4725-4733.

BiJlsma, I.G., VAN DiJK, L., Kusters, J.G., GAASTRA, W. 1995. Nucleotide sequence of two fimbrial subunit genes, $p m p A$ and ucaA from canine uropathogenic Proteus mirabilis strains. Microbiology. 141: 1349-1357.

Bloch, J., Lemaire, X., Legout, L., Ferriby, D., YAZDANPANAH, Y., SENNEVILle, E. 2010. Brain abscesses during Proteus vulgaris bacteremia. Neurol. Sci. 32: 661-663.

CARson, L., CATHCART, G.R., ScotT, C.J., HollenberG, M.D., WAlKer, B., Ceri, H., GILMORE B.F. 2011 Comprehensive inhibitory profiling of the Proteus mirabilis metalloprotease virulence factor ZapA (mirabilysin). Biochemie. 93:1824-1827.

Carson, L., Gorman, S.P., Gilmore, BF. 2010. The use of lytic bacteriophages in the prevention and eradication of biofilms of Proteus mirabilis and Escherichia coli. FEMS Immunol. Med. Microbiol. 59: 447-455.

Chippendale, G.R., Warren, J.W., Trifillis, A.L., MOBLEY, H.L.T. 1994. Internalization of Proteus mirabilis by human renal epithelial cells. Infect. Immun. 62: 3115-3121.

Chlabicz, S., LeszCZyŃSKa, K., LuKAs, W., GuAlCO, L., Schito, G., NABER, K.G. 2011. Uncomplictaed lower urinary tract infections in females-clinical aspects, aetiology and antimicrobial resistance epidemiology. Results of the ARESC (Antimicrobial Resistance Epidemiological Survey on Cystitis) study in Poland on their implications for empiric therapy. Przegl. Epidemiol. 65: 345351. (In Polish).

Coker, C., Poore A., Li, X., Mobley, H.L.T. 2000. Pathogenesis of Proteus mirabilis urinary tract infections. Microb. Infect. 2: 1497-1505.

Daniels, R., VAnderleyden, J., Michiels, J. 2004. Quorum sensing and swarming migration in bacteria. FEMS Microbiol. Rev. 28: 261-289.

Donlan, R.M., COSTERTON, J.W. 2002. Biofilms: survival mechanism of clinically relevant microorganisms. Clin. Microbiol. Rev. 15: 167193.

Doufour, A., Furness, R.B., Hughes, C. 1998. Novel genes that upregulate the Proteus mirabilis flhDC master operon controlling flagellar biogenesis and swarming. Mol. Microbiol. 29: 741-751.

Drechsel, H.A., ThIECKEN, A., ReISSBROdT, R., JUNG, G., WINKELMANN, G. 1993. $\alpha$-keto acids are novel siderophores in the genera Proteus, Providencia and Morganella and are produced by amino acid deaminases. J. Bacteriol. 175: 2727-2733.
Drzewiecka, D., Arbatsky, N.P., ShashKov, A.S., StACCZEK, P., KNIREL, Y.A., SIDORCZYK, Z. 2008. Structure and serological properties of the Oantigen of two clinical Proteus mirabilis strains classified into a new Proteus O77 serogroup. FEMS Immunol. Med. Microbiol. 54: 185-194.

DrZEWIECKA, D., ARBATSKY, N.P., STĄCZEK, P., SHASHKOV, A.S., KNIREL, Y.A., SIDORCZYK, Z. 2010. Structure and serological studies of the Opolysaccharide of strains from a newly created Proteus $\mathrm{O} 78$ serogroup prevalent in Polish patients. FEMS Immunol. Med. Microbiol. 58: 269-276.

DRZEWIECKA, D., SIDORCZYK, Z. 2005. Characterization of Proteus penneri species human opportunistic pathogens. Post. Mikrobiol. 44: 113-126. (In Polish).

DRZEWIECKA, D., ZYCH, K. SIDORCZYK, Z. 2004. Characterization and serological classification of a collection of Proteus penneri clinical strains. Arch. Immunol. Therap. Exp. 52:121-128.

Dumanski, A.J., Hedelin, H., EdIN-Liljegren, A., BeACHEMIN, D., MCLEAN, R.J.C. 1994. Unique ability of Proteus mirabilis capsule to enhance mineral growth in infectious urinary calculi. Infect. Immun. 62: 2998-3003.

FlanNery, E., Mody, L., Mobley, H.L.T. 2009. Identification of a modular pathogenicity island that is widespread among urease-producing uropathogens and shares features with diverse group of mobile elements. Infect. Immun. 77: 4887-4894.

Fujihara, M., Obara, H., WATANabe, Y., OnO, H.K., SASAKI J., GORYO, M., HARASAWA, R. 2011. Acidic environments induce differentiation of Proteus mirabilis into swarmer morphotypes. Microbiol. Immunol. 55: 489-493.

Giammanco, G.M., Grimont, P.A., Grimont, F., LefeVre, M., Giammanco, G., Pignato, S. 2011. Phylogenic analysis of the genera Proteus, Morganella, Providencia by comparison of rpoB gene sequence of type and clinical strains suggests reclassification of Proteus myxofaciens in a new genus, Cosenzaea gen. nov., as Cosenzaea myxofaciens comb. nov. Int. J. Syst. Evol. Microbiol. 61:1638-1644.

Gygi, D., Rahman, M.M., Lai, H.C., Carlson, R., Guard-Petter, J., Hughes, C. 1995. A cell surface polysaccharide that facilitates rapid population migration by differentiated swarm cells of Proteus mirabilis. Mol. Microbiol. 17: 11671175 .

HART, B.R., BLUMENTHAL, R.M. 2010. Unexpected coregulator range in the global regulator Lrp of Escherichia coli and Proteus mirabilis. J. Bacteriol. 193: 1054-1064. 
Hart, B.R., Mishra, P.K., Linter, R.E., Hinerman, J.M., HERR, A.B., BLUMENTHAL, R.M. 2011. Recognition of DNA by the helix-turn-helix global regulatory protein Lrp is modulated by the amino terminus. J. Bacteriol. 193:3794-3803.

HATT, J.K., RATHER, P.N. 2008. Characterization of novel gene, wosA, regulating FlhDC expression in Proteus mirabilis. J. Bacteriol. 190: 1946-1955.

Hay, N.A., Tipper, D., Gygi, D., Hughes, C. 1997. A nonswarming mutant of Proteus mirabilis lacks the Lrp global transcriptional regulator. J. Bacteriol. 179: 4741-4746.

Himpsi, S.D., PeArson, M.M., AREWANG, C.J., NusCA T.D., SHERMAN D.H., MOBLEY, H.L.T. 2010. Proteobactin and a yersiniabactin-related siderophore mediate iron acquisition in Proteus mirabilis. Molec. Microbiol. 78: 138-157.

HoLST, O. 1999. Chemical structure of the core region of lipopolysaccharides. In: H. BRADE, S.M. OPAL, S.N. VOGEL, D.C. MORRISON (eds). Endotoxin in health and disease. Marcel Dekker, Inc. New York, Basel, pp. 115-154.

Jacobsen, S.M., Stickler D.J., Mobley, H.L.T., SHIRTLIFF, M.E. 2008. Complicated catheterassociated urinary tract infections due to Escherichia coli and Proteus mirabilis. Clin. Microbiol. Rev. 21: 26-59.

JANDA, J.M., ABBOT, S.L. 2006. The Enterobacteriaceae. ASM Press. Washington. 233259.

Jansen, A.M., LockAtell, C.V., Johnson, D.E., MoBley, H.L.T. 2004. Mannose-resistant Proteuslike fimbriae are produced by most Proteus mirabilis strains infecting the urinary tract, dictate the in vivo localization of bacteria, and contribute to biofilm formation. Infect. Immun. 72: 7292-7305.

JANSEN, B.V., LOCKATELl, C.V., JOHNSON, D.E., MoBley, H.L.T. 2003. Visualisation of Proteus mirabilis morphotypes in the urinary tract: the elongated swarmer cell is rarely observed in ascending urinary tract infection. Infect. Immun. 71: $3607-3613$.

Jones, B.D., LOCKATELl, C.V., JOHNSON, D.E., WARrEN, J.W., MOBLEY, H.L.T. 1990. Construction of urease-negative mutant of Proteus mirabilis: analysis of virulence in mouse model of ascending urinary tract infection. Infect. Immun. 58: 11201123.

Jones, S.M., Yerly, J., Hu, Y., Ceri, H., MARTinuzZI, R. 2007. Structure of Proteus mirabilis biofilm grown in artificial urine and standard laboratory media. FEMS Microbiol. Lett. 268:16021.

Jones, S.M., DANG, T., MARTINUZzI, R. 2009. Use of quorum sensing antagonists to deter the formation of crystalline Proteus mirabilis biofilm. Int. J. Antimicrob. Agen. 34: 360-364.

KaCA, W., Arabski, M., FudaŁa, R., Holmstrom, E., Sjoholm, A., Weintraub, A., Futoma-Koloch., B., Bugla-PŁoskońsKa, G., DoroszKIEWICZ, W. 2009. Human complement activation by smooth and rough Proteus mirabilis lipopolysaccharides. Arch. Immunol. Ther. Exp. 57: 383-391.

KaCA, W., GlensKa, J., LACHOWICZ, L., GRABOWSKI, S., BRAUnER, A., KWINKOWSKI, M. 2011. Serotyping of Proteus mirabilis clinical strains based on lipopolysaccharide, O-polysaccharide and core oligosaccharide structures. Biochemistry (Moscow). 76: 851-861.

KaCA, W., UjaZDA, E. 1998. Complement activation by bacterial endotoxin. Post. Mikrobiol. 37: 421427. (In Polish).

Kalra, A., CoOley, C., Tsigrelis, C. 2011. Treatment of endocarditis due to Proteus species: a literature review. Int. J. Infect. Dis. 15: 222-225.

Knirel, Y.A., Perepelov, A.V., Kondakova, A., SENCHEKOVA, S.N., SIDORCZYK, Z., RÓŻALSKI, A., KACA, W. 2011. Structure and serology of Oantigens as the basis for classification of Proteus strains. Inn. Immun. 17: 70-96.

Koronakis, V., Cross, M., Senior, B., Koronakis, E., Hughes, C. 1987. The secreted hemolysins of Proteus mirabilis, Proteus vulgaris, and Morganella morganii are genetically related to each other and to the alpha-hemolysin of Escherichia coli. J. Bacteriol. 169: 1509-1515.

KWIECIŃSKA-PIRÓG, J. 2010. Estimation of production of biofilm by Proteus mirabilis bacilli. Ph.D. thesis. Nicolas Copernicus University of Torun. Collegium Medicum in Bydgoszcz. (In Polish).

KWIL, I., BABICKA, D., StĄCZEK, P., RÓŻAlski, A. 2002. Applying the PCR metod for searching genes encoding main structural fimbrial proteins. In: $5^{\text {th }}$ Conference on Molecular biology in diagnostics of infectious disease and biotechnology. Warsaw, SGGW Publisher. 88-91.

KWIL, I. 2003. Investigations of selected virulence factors of Proteus penneri strains. Ph.D. thesis. University of Lodz. (In Polish).

Kwil, I., Biegańska, H., Obarek, K., RÓŻalski, A. 2006. Expression of selected virulence factors among new bacterial species from the genus Proteus: P. hauseri and Proteus genomospecies 4, 5, 6. In: $9^{\text {th }}$ Conference on molecular biology in diagnostics of infectious disease and biotechnology. Warsaw, SGGW Publisher. 93-96.

Lane, M.C., Pearson, M.M., Simms, A.N., Mobley, H.L.T. 2009. Oxygen-limiting conditions enrich for fimbriate cells of uropathogenic Proteus mirabilis and Escherichia coli. J. Bacteriol. 191: 1382-1392. 
Lee, K.K., Harrison, B.A., Latta, R., Altman, E. 2000. The binding of Proteus mirabilis nonagglutinating fimbriae to ganglio-series asialoglycolipids and lactosyl ceramide. Can. J. Microbiol. 46: 961-966.

LI, X., Johnson, D.E., Mobley, H.L.T. 1999. Requirement of $\mathrm{MrpH}$ for mannose-resistant Proteus-like fimbria- mediated hemagglutination by Proteus mirabilis. Infect. Immun. 67: 2822-2833.

Li, X., Lockatell, C.V., Johnson, D.E., Mobley, H.L.T. 2002a. Identification of MrpI as the sole recombinase that regulates the phase variation of $\mathrm{MR} / \mathrm{P}$ fimbria, a bladder colonization factor of uropathogenic Proteus mirabilis. Mol. Microbiol. 45: 865-874.

Li, X., Zhao, H., Lockatell, C.V., DrachenberG, C.B., Johnson, D.E., Mobley, H.L.T. 2002 b. Visualization of Proteus mirabilis within the matrix of urease-induced bladder stones during experimental urinary tract infection. Infect. Immun. 70: 389-394.

LiAW., S.J., LAI, H.C., Ho, S.W., LUH, K.T., WANG, W.B. 2003. Role of RsmA in the regulation of swarming motility and virulence factor expression in Proteus mirabilis. J. Med. Microbiol. 52: 19-28.

LIAW, S.J., LAI, H.C., WANG., W.B. 2004. Modulation of swarming and virulence by fatty acids trough the RsbA protein in Proteus mirabilis. Infect. Immun. 72: 6836-6845.

LoOMes, L.M., Senior, B.W., KerR, M.A. 1990. A proteolytic enzyme secreted by Proteus mirabilis degrades immunoglobulins of the immunoglobulin A1 (IgA1), IgA2, and IgG isotypes. Infect. Immun. 58: 1970-1985.

ŁUKASIEWICZ, J., ŁUGOWSKI, C. 2003. Biological activities of lipopolysaccharide. Post. Hig. Med. Doświad. 57: 33-53. (In Polish).

MAlic, W., WAtTERs, M,G., BAsil, L., Stickler, D.J., WILLIAMS, D.M. 2011. Development of an "early warning" sensor for encrustation of urinary catheters following Proteus infection. J. Biomed. Mater Res. B Appl. Biomater. DOI: 10.1002/jbm.b.31930.

Massad, G., ZhaO, H., Mobley, H.L.T. 1995. Proteus mirabilis aminoacid deaminase: cloning, nucleotide sequence, and characterization of aad. J. Bacteriol. 177: 5878-5883.

Mielnik, G., DoroszKIEWICZ, W., KorZENIOWSKAKowAL, A. 2004. External structures of Gramnegative bacteria and bactericidal activity of complement. Post. Mikrobiol. 43: 39-57. (In Polish).

Mobley, H.L.T. 1996. Virulence of Proteus mirabilis. In: H.L.T. MOBLEY, J.W. WARREN (eds.) Urinary tract infections, molecular pathogenesis and clinical management. ASM Press, Washington DC, pp. 245-269.

Mobley, H.L.T, Belas, R., LOckATEll, V., Chippenadale, G., Trifillis A.L., Johnson, D.E., WARREN, J.W. 1996. Construction of a flagellumnegative mutant of Proteus mirabilis: effect on internalization by human renal epithelial cells and virulence in a mouse model of ascending urinary tract infection. Infect. Immun. 64: 5332-5340.

Mobley, H.L.T., ISLAND, M.D., HAUSINGER, R.P. 1995. Molecular biology of microbial ureases. Microbiol. Rev. 59: 451-480.

Morgenstein, R.M., SzosteK, B., RAther, P.N. 2010. Regulation of gene expression during swarmer cell differentiation in Proteus mirabilis. FEMS Microbiol. Rev. 34: 753-763.

MORYL, M. 2010. Investigations of biofilm formation by Proteus mirabilis and its sensitivity to antibacterial agents. Ph.D. Thesis. University of Lodz. (In Polish).

MORYL, M., TORZEWSKA, A., RÓŻALSKI, A. 2008. Substances affecting Proteus mirabilis biofilm. In: Conference "Vaccines: Advances in plant and microbial biotechnology, infectious immunity and cancer therapy. Warsaw, SGGW Publisher. 179181.

Nielubowicz, G., Mobley, H.L.T. 2010. Hostpathogen interactions in urinary tract infections. Nature Rev. Urology 7: 430-441.

O' Hara, C., Brenner, F.W., Miller, J.M. 2000. Classification, identification, and clinical significance of Proteus, Providencia, and Morganella. Clin. Microbiol. Rev. 13: 534-546.

Okimoto, N., Hayashi, T., Ishiga, M., NANBA, F., Kishimoto, M., Yagi, S., Kurihara, T., AsoKA, N., TAMADA, S. 2010. Clinical features of Proteus mirabilis pneumonia. J. Infect. Chemother. 16: 364-366.

PALUSIAK, A., SIDORCZYK, Z. 2009. Serological characterization of the core region of lipopolysaccarides of rough Proteus sp. strains. Arch. Immunol. Ther. Exp. 57: 303-310.

PALUSIAK, A., SIDORCZYK, Z. 2010. Characterization of epitope specificity of Proteus penneri 7. ABP. 57: 529-532.

Pearson, M.M., Mobley, H.L.T. 2008. Repression motility during fimbrial expression; identification of 14 mrpJ gene paralogues in Proteus mirabilis. Mol. Microbiol. 69: 548-558.

PERSON, M.M. et al. 2008. Complete genome sequence of uropathogenic Proteus mirabilis, a master of both adherence and motility. J. Bacteriol. 190: 4027-4037. 
Phan, V., Belas, R., Gilmore, B.F., Ceri, H. 2008. ZapA, a virulence factor in a rat model of Proteus mirabilis-induced acute and chronic prostatitis. Infect. Immun. 76: 4859-4864.

Piechota, J., Prywer, J., Torzewska, A. 2012. $A b$ initio prediction of structural and elastic properties of struvite: contribution to urinary stone research. Comput. Meth. Biochem. Engin. 15: 1329-1336.

PRYWER, J., TORZEWSKA, A. 2009. Bacterially induced struvite growth from synthetic urine: experimental and theoretical characterization of crystal morphology. Cryst. Growth Design. 9: 3538-3543.

PRYWER, J., TORZEWSKA, A. 2010. Biomineralization of struvite crystals by Proteus mirabilis from artificial urine and their mesoscopic structure. Cryst. Res. Technol. 45: 1283-1289.

Prywer, J., TORZEWSKA, A. 2012. Effect of curcumin against Proteus mirabilis during crystallization of struvite form artificial urine. Evidence Base Complementary and Alternative Medicin. 862794: $1-7$.

RADZIEJEWSKA-LeBrecht, J., MAYeR, H. 1989. The core region of Proteus mirabilis R110/1959 lipopolysaccharide. Eur. J. Biochem. 183: 573-581.

RAETZ, C.R., WHITFIELD, C. 2002. LIPOPOLYSACCHARIDE ENDOTOXIN. ANN. REV. BIOCHEM. 71: 635-700.

RATHER, P.N. 2005. Swarmer cell differentiation in Proteus mirabilis. Environm. Microbiol. 7: 10651073.

Rocha, S.P.D., Elias, W.P., Cianciarullo, A.M., MENEZES M.A., NARA, J.M., PIAZZA, R.F.M., SILVA, M.R.L., MOREIRA, C.G., PElAYO, J.S. 2007a. Aggregative adherence of uropathogenic Proteus mirabilis to cultured epithelial cells. FEMS Immunol. Med. Microbiol. 51: 319-326.

Rocha, S.P.D., Elias, W.P., Pelayo, J.S. $2007 \mathrm{~b}$. Fimbriae of uropathogenic Proteus mirabilis. FEMS Immunol. Med. Microbiol. 51: 1-7.

ROMANOWSKI, Z., KEMPISTY, P., PRYWER, J., KRUKOWSKI, S., TORZEWSKA A. 2010. Density functional theory determination of structural and electronic properties of struvite: J. Phys. Chem. 114: 7800-7808.

RÓŻALSKI, A. 2002. Molecular basis of the pathogenicity of Proteus bacteria. Adv. Clin. Exp. Med. 11: 3-18.

RÓŻALSKI, A. 2004. Lipopolysaccharide and others virulence factors of Proteus bacteria. Post. Mikrobiol. 43: 409-431. (In Polish).

RÓŻALSKI, A. 2008. Lipopolysaccharide (LPS, endotoxin) of Proteus bacteria - chemical structure, serological specificity and the role in pathogenicity. Folia Biolog. Oecolog. 4: 5-24.
RÓŻAlski, A., DŁugońsKa, H., KoteŁKo, K. 1986. Cell invasiveness of Proteus mirabilis and Proteus vulgaris strains. Arch. Immunol. Ther. Exp. 34: 505-511.

RÓŻALSKI, A., KoteŁKO, K. 1987. Hemolytic activity and invasiveness in strains of Proteus penneri. J. Clin. Microbiol. 25: 1094-1096.

RÓŻalski, A., SidorczyK, Z., KoteŁKO, K. 1997. Potential virulence factors of Proteus bacilli. Microbiol. Mol. Biol. Rev. 61: 65-89.

RÓżAlski, A., StąCzEK, P. 2010. Proteus. In: D. LIU, (ed.) Molecular detection of foodborne pathogens. CRS Press, Taylor and Francis Group. Boca Raton, p. 417-430.

RÓŻAlsKi, A., StĄCZEK, P. 2011. Proteus. In: Molecular detection of human bacterial pathogens. In: D. Liu (ed.), CRC Press, Taylor and Francis Group. Boca Raton, p. 981-996.

RÓŻAlski, A., TORZEWSKA, A., BARTODZIEJSKA B., BABICKA D., KWIL, I., PEREPELOV, A.V., Kondakova, A.N., SENChEnKOVA, S.N., KNIREL, Y.A., VINOGRADOV, E.V. 2002. Chemical structure, antigenic specificity, the role in the pathogenicity of lipopolysaccharide (LPS, endotoxin) one the Proteus vulgaris bacteria's example. Wiadomości Chemiczne. 56: 585-604. (In Polish).

Scavone, P., UMPIERreZ, A., Maskell, D.J., ZuninO, P. 2011. Nasal immunization with attenuated Salmonella Thyphimurium expressing and MrpATetC fusion protein significantly reduces Proteus mirabilis colonization in mouse urinary tract. J. Med. Microbiol. 60: 899-904.

Schlapp, G., Scavone, P., Zunino, P., Hartel, S. 2011. Development of 3D architecture of uropathogenic Proteus mirabilis bath culture biofilms - A quantitative confocal microscopy approach. J. Microbiol. Meth. 87: 234-240.

SidORCZYK, Z., ZAHRINGER, U., RIETSCHEL, E.T. 1983. Chemical structure of the lipid A component of the lipopolysacharide of Proteus mirabilis Re mutant. Eur. J. Biochem. 137: 15-22.

SosA, V., Zunino, P. 2009. Effect of Ibicella lutea on uropathogenic Proteus mirabilis growth, virulence and biofilm formation. J. Infect. Dev. Ctries. 3: 762-770.

Stańkowska, D., Czerwonka, G., Różalska, S., GrosickA, M., DZIADEK, J., KACA, W. 2012. Influence of quorum sensing signal molecules on biofilm formation in Proteus mirabilis O18. Folia Microbiol. 57: 53-60.

StAŃKOwsKA, D., KwINKOWsKI, M., KACA, W. 2008. Quantification of Proteus mirabilis virulence factors and modulation by acylated homoserine lactones. J. Microbiol. Immunol. Infect. 41: 243253. 
STICKLER, D.J., 2008. Bacterial biofilms in patients with indwelling urinary catheters. Nature Clin. Pract. Urology. 5: 598-607.

Stickler, D.J., FEnEley, R.C.L. 2010. The encrustation and blockage of long-term indwelling bladder catheters: a way forward in prevention and control. Spinal Cord. 48: 784-790.

SWIHART, K.G., Welch, R.A. 1990. Cytotoxic activity of Proteus hemolysin HpmA. Infect. Immun. 58: 1861-1869.

TORZEWSKA, A., RóżAlski, A. 2009. Studies on infection-induced urinary calculi formation in the presence of glycosaminoglycans. X Jubilee Conference "Molecular biology in diagnostic of infectious diseases and biotechnology, Warsaw University of Life Sciences - SGGW, 2009. Scientific materials, 179-182.

Torzewska, A., StączeK, P., RóżALSKI, A. 2003. The crystallization of urine mineral components may depend on the chemical nature of Proteus endotoxin polysaccharides. J. Medical. Microbiol. 52: $471-477$.

TORZEWSKA, A., ZIELIŃSKA, E., ŚWIDER, S., RÓŻALSKI, A. 2010. Influence of curcumin on Proteus mirabilis pathogenicity. Sepsis. 4: 276-277.

UPHOFF, T.S., WELCH, R.A. 1990. Nucleotide sequencing of the Proteus mirabilis calcium independent hemolysin genes (hpmA and hpmB) reveals sequence similarity with Serratia marcescens hemolysin genes (shlA and $s h l B)$. J. Bacteriol. 172: 1206-1216.

Verstraeten, N., Brekanen, K., Debkumari, B., FAUVART, M., FRANSAER, J., VERMANT J., MiCHIELS, J. 2008. Living on a surface: swarming and biofilm formation. Trends Microbiol. 16: 496506.

VINOGRADOV, E. 2011. Structure of the core part of the lipopolysaccharide form Proteus mirabilis genomic strain HI4320. Biochemistry (Moscow). 76: 803807.

Vinogradov, E.V., SidorczyK, Z., KnIREL, Y.A. 2002. Structure of lipopolysaccharide core region of the genus Proteus. Aust. J. Chem. 55: 61-67.

Vinogradov, E.V., Thomas-OAtes, E., Brade, H., HoLST, O. 1994. Structural investigations of the lipopolysaccharide from Proteus mirabilis R45 (Re-chemotype). J. End. Res. 1: 199-206.

WAnG, Q., TORZEWSKA, A., RUAN, X., WANG, X., RÓŻALSKI, A., ShaO, Z., GUO, X., FENG, L., WANG, L. 2010. Molecular and genetic analyses of the putative Proteus O-antigen gene locus. App. Env. Microbiol. 76: 5471-5480.

WARREN, J.W. 1996. Clinical presentations and epidemiology of urinary tract infections. In: H.L.T.
MOBLEY, J.W. WARREN (eds.) Urinary tract infections, molecular pathogenesis and clinical management. ASM Press, Washington DC, p. 2-28.

Wray, S.K., Hull, S.I., CoOK, R.G., Barrish, J., HULL, R.A. 1986. Identification and characterization of a uroepithelial cell adhesion from a uropathogenic isolate of Proteus mirabilis. Infect. Immun. 54: 43-49.

Zunino, P., Geymont, L., Allen, A.G., LegnaniFAJARDO, C., MASKELL, D.J. 2000. Virulence of Proteus mirabilis atf isogenic mutant is not impaired in a mouse model ascending urinary tract infection. FEMS Immunol. Med. Microbiol. 29: 137-143.

Zunino, P., Piccini, C., Legniani-Fajardo, C. 1994. Flagellate and non flagellate Proteus mirabilis in the development of experimental urinary tract infection. Microb. Path. 16: 379-385.

Zunino, P., Sosa, V., Shlapp, G., Allen, A.G., PRESTON A., MASKELl, D.J. 2007. Mannoseresistant Proteus-like and Proteus mirabilis fimbriae have specific and additive roles in P. mirabilis urinary tract infections. FEMS Immunol. Med. Microbiol. 51: 125-133. 